\title{
UJI AKTIVITAS EKSTRAK DAUN SEPAT (Mitragyna speciosa) TERHADAP PENURUNAN KADAR GLUKOSA DARAH MENCIT (Mus Musculus)
}

\author{
Ayu Indah Cahyani*, Mukti Priastomo, Adam M. Ramadhan \\ Laboratorium Penelitian dan Pengembangan FARMAKA TROPIS \\ Fakultas Farmasi Universitas Mulawarman, Samarinda, Kalimantan Timur \\ *email: yuyuin96@gmail.com
}

\begin{abstract}
ABSTRAK
Tumbuhan sepat merupakan tumbuhan dari famili rubiceae, yang biasa digunakan sebagai obat tradisional dalam menurunkan kadar glukosa darah. Daun sepat memiliki kandungan kimia alkaloid yang diduga memiliki efek dalam menurunkan kadar glukosa darah. Penelitian ini bertujuan untuk mengetahui aktivitas ekstrak daun sepat, mengetahui dosis terbaik dan mengetahui potensinya dalam menurunkan kadar glukosa darah mencit ( Mus musculus). Metode penelitian yang digunakan adalah secara in vivo dengan menggunakan hewan coba mencit jantan yang diberikan beban sukrosa $50 \%$ secara oral. Hewan coba dibagi menjadi 5 kelompok yaitu kelompok 1 (diberi suspensi Na CMC 0,5\%), kelompok 2 (glibenklamid), kelompok 3 (ekstrak dosis $100 \mathrm{mg} / \mathrm{kg}$ bb), kelompok 4 (ekstrak dosis $200 \mathrm{mg} / \mathrm{kg}$ bb), kelompok 5 (ekstrak dosis $400 \mathrm{mg} / \mathrm{kg}$ bb). Kadar glukosa darah mencit didapatkan dari pengukuran menggunakan alat glukometer. Dari hasil pengujian diketahui bahwa ekstrak daun sepat memiliki aktivitas dalam menurunkan kadar glukosa darah mencit. Dosis efektif ekstrak daun sepat dalam menurunkan kadar glukosa darah yaitu dosis $200 \mathrm{mg} / \mathrm{kg}$ bb.
\end{abstract}

Kata kunci: Daun sepat, glukometer, sukrosa

\begin{abstract}
Sepat is a plant of the family Rubiaceae and has a plant alkaloid chemical content that allegedly had an effect in lowering blood glucose levels. This study aims to determine the activity of the leaf extract Sepat, determine the best dose and determine its potential in lowering blood glucose levels in mice (Mus musculus). The method used is in vivo using animals male mice given the burden of 50\% oral sucrose. Animals were divided into 5 groups: group 1 (by suspension of $\mathrm{Na} C M C$ 0,5\%), group 2(glibenclamid) group 3 (extract dose of $100 \mathrm{mg} / \mathrm{kg} \mathrm{bw}$ ), group 4 (extract dose of $200 \mathrm{mg} / \mathrm{kg} \mathrm{bw}$ ), group 5 (extract dose of $400 \mathrm{mg} / \mathrm{kg} \mathrm{bw}$ ). Blood glucose levels in mice obtained from measurements using a glucometer. From the test results it is known that the leaf extract Sepat have activity in lowering blood glucose levels in mice. The effective dose leaf extract Sepat in lowering blood glucose level is $200 \mathrm{mg} / \mathrm{kg} \mathrm{bw}$.
\end{abstract}

Keywords: sepat leaf, glucometer, sucrose 


\section{PENDAHULUAN}

Sumber senyawa bahan alam hayati memegang peranan penting dalam pemanfaatan zat kimia berkhasiat yang terdapat di alam. Hampir setiap daerah di Indonesia mengenal ramuan obat yang berasal dari tumbuh-tumbuhan yang digunakan untuk pengobatan tertentu secara tradisional. Penggunaan tumbuh-tumbuhan tertentu sebagai obat merupakan warisan turun-temurun dari nenek moyang kita sejak dahulu hingga sekarang. Bahan obat yang digunakan dapat berasal dari daun, batang, akar, bunga dan biji-bijian (Siregar, 2005).

Penggunaan obat tradisional dalam masyarakat masih berdasarkan tradisi secara turun-temurun sehingga perlu dilakukan penelitian tentang obat tradisional agar penggunaannya dapat lebih aman dan efektif. Selain penggunaan obat sintesis, tanaman obat juga banyak digunakan untuk menurunkan kadar glukosa darah. Komponen bahan aktif dari beberapa tanaman obat memiliki aktivitas biologis dalam menurunkan kadar glukosa darah (Purintrapiban, 2011).

Daun sepat dikenal dalam pengobatan tradisional untuk menurunkan kadar glukosa darah. Daun sepat mengandung metabolit sekunder berupa alkaloid yang diduga memiliki aktivitas dalam menurunkan kadar glukosa darah.

Tujuan penelitian ini yaitu untuk mengetahui aktivitas ekstrak daun sepat, mengetahui dosis efektif ekstrak daun sepat dalam menurunkan kadar glukosa darah mencit dan mengetahui potensi ekstrak daun sepat dibanding glibenklamid.

\section{METODOLOGI PENELITIAN}

\section{Bahan dan Alat}

Bahan yang digunakan yaitu daun sepat, metanol, aquades, sukrosa, dan $\mathrm{Na}$ CMC. Alat yang digunakan yaitu rotary evaporator, gunting, spuid, sonde, gelas kimia, batang pengaduk, labu ukur, corong kaca, mortir dan stamper, strip gula darah dan alat ukur gula darah Easy Touch®.

\section{Pembuatan Simplisia}

Daun Sepat dibersihkan dan dicuci bersih dengan air mengalir, ditiriskan kemudian dirajang kecil-kecil dengan menggunakan gunting, selanjutnya dikeringkan dengan cara diangin-anginkan tanpa terkena sinar matahari langsung. Setelah kering, sampel disortasi atau dibersihkan dari kotoran yang mungkin ikut tercampur.

\section{Pembuatan Ekstrak Metanol Daun Sepat}

Pembuatan ekstrak metanol daun sepat dilakukan dengan metode maserasi. Daun sepat kering dimasukkan ke dalam toples kemudian ditambahkan pelarut metanol dan dimaserasi selama 2 x 24 jam. Ekstrak kemudian disaring dengan kertas saring dan dilakukan remaserasi dengan pelarut metanol. Ekstrak daun sepat dipekatkan dengan menggunakan rotary evaporator pada suhu $50^{\circ} \mathrm{C}$. Ekstrak kental dikeringkan dengan cara diangin-anginkan.

\section{Pengujian Metabolit Sekunder}

\section{a. Uji Alkaloid}

Ekstrak (2 mL) diuapkan di atas cawan porselin. Residu yang dihasilkan kemudian dilarutkan dengan $5 \mathrm{~mL} \mathrm{HCl} 2 \mathrm{M}$. Larutan yang diperoleh dibagi ke dalam 3 tabung reaksi. Tabung pertama berfungsi sebagai blanko, ditambahkan dengan 3 tetes $\mathrm{HCl} 2 \mathrm{M}$. Tabung kedua ditambahkan 3 tetes pereaksi Dragendorff dan tabung ketiga ditambahkan 3 tetes pereaksi Mayer. Uji positif ditunjukkan dengan terbentuknya endapan berwarna jingga sedangkan pereaksi Mayer dengan terbentuknya endapan berwarna kuning. 


\section{b. Uji Fenolik}

Ekstrak $(1 \mathrm{~mL})$ dimasukkan ke dalam tabung reaksi, kemudian ditambahkan pereaksi $\mathrm{FeCl}_{3} 1 \%$. Uji positif ditunjukkan dengan terbentuknya warna hitam.

\section{c. Uji Flavonoid}

Ekstrak ( $2 \mathrm{~mL})$ ditambahkan dengan air panas, kemudian dididihkan selama 5 menit lalu disaring. Filtrat sebanyak $5 \mathrm{~mL}$ ditambahkan $0,05 \mathrm{mg}$ serbuk $\mathrm{Mg}$ dan $1 \mathrm{~mL} \mathrm{HCl}$ pekat, kemudian dikocok. Uji positif ditunjukkan dengan terbentuknya warna merah, kuning atau jingga.

\section{d. Uji Saponin}

Ekstrak (2-3 mL) dimasukkan ke dalam tabung reaksi, kemudian ditambahkan dengan $10 \mathrm{~mL}$ air panas lalu didinginkan dan dikocok kuat selama 10 detik, lalu ditambahkan 1 tetes $\mathrm{HCl} 2 \mathrm{~N}$. Uji positif ditunjukkan dengan terbentuknya buih yang stabil setinggi $1-10 \mathrm{~cm}$ selama 10 menit.

\section{e. Uji Steroid dan Terpenoid}

Ekstrak ( $2 \mathrm{~mL}$ ) ditambahkan asam asetat glasial dan $\mathrm{H}_{2} \mathrm{SO} 4$ pekat, kemudian larutan dikocok perlahan. Uji positif steroid ditunjukkan dengan terbentuknya warna biru atau hijau, sedangkan triterpenoid memberikan warna merah atau ungu.

\section{f. Uji Tanin}

Ekstrak (1 mL) ditambahkan dengan beberapa tetes larutan $\mathrm{FeCl}_{3} 10 \%$. Uji positif ditunjukkan dengan terbentuknya warna hitam kehijauan.

\section{Pembuatan Suspensi Na CMC 0,5\%}

Sebanyak 0,5 gram Na CMC ditaburkan ke dalam mortir yang berisi $30 \mathrm{~mL}$ aquades panas dan didiamkan selama 15 menit hingga diperoleh massa yang transparan, kemudian digerus sampai homogen. Selanjutnya diencerkan dengan aquades dan dimasukkan ke dalam labu ukur $100 \mathrm{~mL}$. Volume dicukupkan sampai tanda batas.

\section{Pembuatan larutan sukrosa $50 \%$ dalam $5 \mathrm{~mL}$}

Sebanyak 2,5 gram sukrosa dihaluskan kemudian dilarutkan dalam aquades sebanyak $3 \mathrm{~mL}$. Selanjutnya dimasukkan kedalam labu ukur $5 \mathrm{~mL}$ dan dicukupkan volumenya hingga tanda batas.

\section{Pembuatan suspensi glibenklamid}

Dosis glibenklamid pada manusia dewasa adalah $5 \mathrm{mg} / \mathrm{kg}$ bb, maka dosis glibenklamid untuk mencit adalah $0,026 \mathrm{mg} / 40 \mathrm{~g}$ bb mencit. Ditimbang masing-masing tablet glibenklamid sebayak tiga tablet, dihitung rata-rata beratnya. Tiga tablet glibenklamid digerus dan diambil sebanyak 0,26 mg dimasukkan dalam mortir dan ditambahkan suspensi NaCMC 0,5\% sambil digerus hingga homogen kemudian dimasukkan kedalam labu ukur 5 $\mathrm{mL}$ dan ditambahkan suspensi Na CMC hingga tanda batas.

\section{Pembuatan Suspensi Ekstrak Metanol Daun Sepat}

Variasi dosis yang digunakan yaitu ekstrak daun sepat dosis $100 \mathrm{mg} / \mathrm{kg} \mathrm{bb}, 200 \mathrm{mg} / \mathrm{kg}$ $\mathrm{bb}$, dan $400 \mathrm{mg} / \mathrm{kg} \mathrm{bb}$. Setiap dosis ekstrak daun sepat yang digunakan dilarutkan dalam suspensi NaCMC 0,5\% kemudian dicukupkan volume suspensi dalam labu ukur $5 \mathrm{~mL}$ hingga tanda batas. Volume pemberian dihitung berdasarkan berat badan dan diberikan secara per oral. 


\section{Pengujian Aktivitas Ekstrak Daun Sepat dengan Beban Sukrosa}

Hewan uji yang digunakan yaitu mencit jantan yang dikelompokkan dalam 5 kelompok. Sebelum diberi perlakuan, semua hewan uji dipuasakan selama 16 jam (tetap diberikan minum). Semua hewan uji yang telah dipuasakan ditimbang berat badannya kemudian dicek kadar glukosa darah (t0). Semua hewan uji dioralkan larutan sukrosa 50\%. Setelah 15 menit, di cek kadar glukosa darah mencit setelah induksi sukrosa (t1). Diberikan suspensi Na CMC 0,5\% pada kelompok kontrol negatif, diberikan suspensi glibenklamid pada kelompok kontrol positif dan di berikan ekstrak daun sepat pada masing-masing kelompok variasi dosis yaitu dosis $100 \mathrm{mg} / \mathrm{kg} \mathrm{bb}, 200 \mathrm{mg} / \mathrm{kg}$ bb dan $400 \mathrm{mg} / \mathrm{kg}$ bb. Kemudian kadar glukosa darah mencit diukur pada menit ke-15 (t2), menit ke-30 (t3), menit ke-60 (t4), menit ke-90 (t5), dan menit ke-120 (t6).

\section{Analisis Data}

Data yang diperoleh dianalisis secara deskriptif dengan membandingkan selisih penurunan kadar glukosa darah mencit.

\section{HASIL DAN PEMBAHASAN}

\section{Uji Metabolit Sekunder}

Hasil identifikasi metabolit sekunder ekstrak metanol daun sepat diperoleh hasil positif yaitu golongan senyawa alkaloid, saponin, tanin, fenolik, steroid dan triterpenoid. Hasil uji metabolit sekunder dapat dilihat pada tabel 1.

Tabel 1. Uji Metabolit Sekunder Ekstrak Daun Sepat

\begin{tabular}{cccccccc}
\hline Sampel & \multicolumn{7}{c}{ Metabolit Sekunder } \\
\cline { 2 - 7 } Uji & Alkaloid & Flavonoid & Saponin & Tanin & Fenolik & Steroid & Triterpenoid \\
\hline Ekstrak & + & - & + & + & + & + & + \\
Metanol & + & - & + & + & + & & + \\
\hline
\end{tabular}

\section{Pengujian Aktivitas Ekstrak Daun Sepat dengan Beban Sukrosa}

Hewan uji yang digunakan dalam penelitian ini ialah mencit jantan galur swiss webster. Hewan ini dipilih dalam pengujian karena mudah diberi perlakuan, mudah didapat dan harganya relatif murah. Sebelum dilakukan pengujian, mencit dipuasakan selama 16 jam dengan tidak diberikan makanan agar tidak mempengaruhi absorbsi obat dalam tubuh. Setelah dipuasakan, semua mencit dicek kadar glukosa darah (t0). Kenaikan kadar glukosa darah mencit dicapai dengan cara diinduksi sukrosa atau diberikan beban sukrosa $50 \%$.

Penelitian ini terdiri atas 5 kelompok yang terbagi atas kelompok kontrol negatif dengan pemberian suspensi NaCMC 0,5\%, kelompok kontrol positif dengan pemberian glibenklamid, kelompok uji dengan dosis ekstrak daun sepat $100 \mathrm{mg} / \mathrm{kg}$ bb, kelompok uji dengan dosis ekstrak daun sepat $200 \mathrm{mg} / \mathrm{kg}$ bb, dan kelompok uji dengan dosis ekstrak daun sepat $400 \mathrm{mg} / \mathrm{kg} \mathrm{bb}$.

Pengukuran kadar glukosa darah dilakukan sebanyak 7 kali yaitu kadar glukosa darah sebelum dan sesudah induksi sukrosa ( $\mathrm{t} 0$ dan $\mathrm{t} 1$ ), serta kadar glukosa darah pada menit ke 30 (t2), menit ke 60 (t3), menit ke 90 (t4), menit ke 120 (t5), dan menit ke 150 (t6) setelah pemberian sukrosa. Hasil penelitian dapat dilihat pada tabel 2. 
Tabel 2. Hasil pengukuran kadar glukosa darah mencit

\begin{tabular}{cccccc}
\hline & \multicolumn{5}{c}{ Kadar Glukosa Darah (mg/dL) } \\
\cline { 2 - 6 } Waktu & $\begin{array}{c}\text { Kontrol negatif } \\
\text { (Na CMC } \\
0,5 \%)\end{array}$ & $\begin{array}{c}\text { Kontrol Positif } \\
\text { (glibenklamid) }\end{array}$ & $\begin{array}{c}\text { Dosis 100 } \\
\text { mg/kg bb }\end{array}$ & $\begin{array}{c}\text { Dosis 200 } \\
\text { mg/kg bb }\end{array}$ & $\begin{array}{c}\text { Dosis 400 } \\
\text { mg/kg bb }\end{array}$ \\
\hline T0 & 109,2 & 99,2 & 92 & 88,6 & 93,8 \\
T1 & 174,8 & 157 & 148,6 & 165,4 & 164 \\
T2 & 148 & 133,2 & 130,6 & 184,6 & 138,6 \\
T3 & 146,8 & 105,8 & 130,6 & 187,8 & 183,2 \\
T4 & 143,8 & 81 & 114,4 & 183,8 & 218,4 \\
T5 & 123,4 & 61,6 & 120,6 & 185 & 240,2 \\
T6 & 113,4 & 66 & 97,6 & 146,8 & 210,4 \\
\hline
\end{tabular}

Tabel 3. Persentase kenaikan dan penurunan kadar glukosa darah mencit setelah diinduksi sukrosa

\begin{tabular}{cccccc}
\hline Waktu & $\begin{array}{c}\text { Kontrol } \\
\text { Negatif }\end{array}$ & $\begin{array}{c}\text { Kontrol } \\
\text { Positif }\end{array}$ & $\begin{array}{c}\text { Dosis } \\
100 \mathrm{mg} / \mathrm{kg} \\
\mathrm{bb}\end{array}$ & $\begin{array}{c}\text { Dosis } \\
200 \mathrm{mg} / \mathrm{kg} \\
\mathrm{bb}\end{array}$ & $\begin{array}{c}\text { Dosis } \\
400 \mathrm{mg} / \mathrm{kg} \\
\mathrm{bb}\end{array}$ \\
\hline T1 & $60 \%$ & $58 \%$ & $62 \%$ & $87 \%$ & $75 \%$ \\
T2 & $-15 \%$ & $-15 \%$ & $-12 \%$ & $12 \%$ & $-15 \%$ \\
T3 & $-1 \%$ & $-21 \%$ & $0 \%$ & $2 \%$ & $32 \%$ \\
T4 & $-2 \%$ & $-23 \%$ & $-12 \%$ & $-2 \%$ & $19 \%$ \\
T5 & $-14 \%$ & $-24 \%$ & $5 \%$ & $1 \%$ & $10 \%$ \\
T6 & $-8 \%$ & $7 \%$ & $-19 \%$ & $-21 \%$ & $-12 \%$ \\
\hline
\end{tabular}

Keterangan: - : mengalami penurunan kadar glukosa darah

T0: sebelum beban sukrosa

T1: menit ke-15 setelah beban sukrosa (sebelum diberikan ekstrak)

T2: menit ke-15 setelah diberikan ekstrak

T3: menit ke-30 setelah diberikan ekstrak

T4: menit ke-60 setelah diberikan estrak

T5: menit ke-90 setelah diberikan ekstrak

T6: menit ke-120 setelah diberikan ekstrak

Rata-rata kenaikan dan penurunan kadar glukosa darah mencit dengan beban sukrosa antara kelompok kontrol negatif ( $\mathrm{Na} \mathrm{CMC} \mathrm{0,5 \% ),} \mathrm{kelompok} \mathrm{kontrol} \mathrm{positif} \mathrm{(glibenklamid),}$ kelompok uji dosis ekstrak $100 \mathrm{mg} / \mathrm{kg}$ bb, dosis $200 \mathrm{mg} / \mathrm{kg}$ bb dan dosis $400 \mathrm{mg} / \mathrm{kg}$ bb dapat dilihat pada gambar 1.

Berdasarkan grafik rata-rata kadar glukosa darah mencit, terdapat perbedaan penurunan kadar glukosa darah pada kelompok kontrol negatif, kelompok kontrol positif, kelompok uji dosis ekstrak $100 \mathrm{mg} / \mathrm{kg}$ bb, dosis $200 \mathrm{mg} / \mathrm{kg}$ bb, dan dosis $400 \mathrm{mg} / \mathrm{kg} \mathrm{bb}$. Data yang didapat dianalisis dengan metode analisis deskriptif dengan melihat jumlah penurunan kadar glukosa darah mencit pada menit ke-120 (t5) sampai menit ke-150 (t6).

Dari hasil penelitian, dapat dilihat bahwa pada t0 untuk semua perlakuan berada pada kisaran kadar glukosa darah normal hal ini karena mencit belum diinduksi sukrosa dan masih dalam keadaan puasa dimana belum terjadi penyerapan glukosa ke dalam darah. Pada t1 terlihat bahwa semua perlakuan mengalami kenaikan kadar glukosa darah, menunjukkan 
bahwa telah terjadi penyerapan glukosa oleh tubuh hewan uji pada menit ke-15 setelah diinduksi sukrosa. Kelompok kontrol negatif mengalami penurunan kadar glukosa darah hingga menit ke-120 (t6), hal ini dikarenakan kontrol negatif merupakan kelompok hewan uji yang hanya diberikan NaCMC $0,5 \%$ kadar glukosa darah mencit naik kemudian mengalami penurunan karena terjadi eliminasi glukosa pada hewan uji itu sendiri dalam hal ini pengaruh dari kerja insulin (Kurniawan, 2011). Kelompok kontrol positif mengalami penurunan dikarenakan pada kelompok ini diberikan suspensi glibenklamid yang merupakan obat golongan sulfonilurea yang dapat menurunkan kadar glukosa darah. Pada kelompok uji dosis $100 \mathrm{mg} / \mathrm{kg} \mathrm{bb}, 200 \mathrm{mg} / \mathrm{kg} \mathrm{bb}, 400 \mathrm{mg} / \mathrm{kg}$ bb terjadi kenaikan kadar glukosa darah kemudian terjadi penurunan kadar glukosa darah.

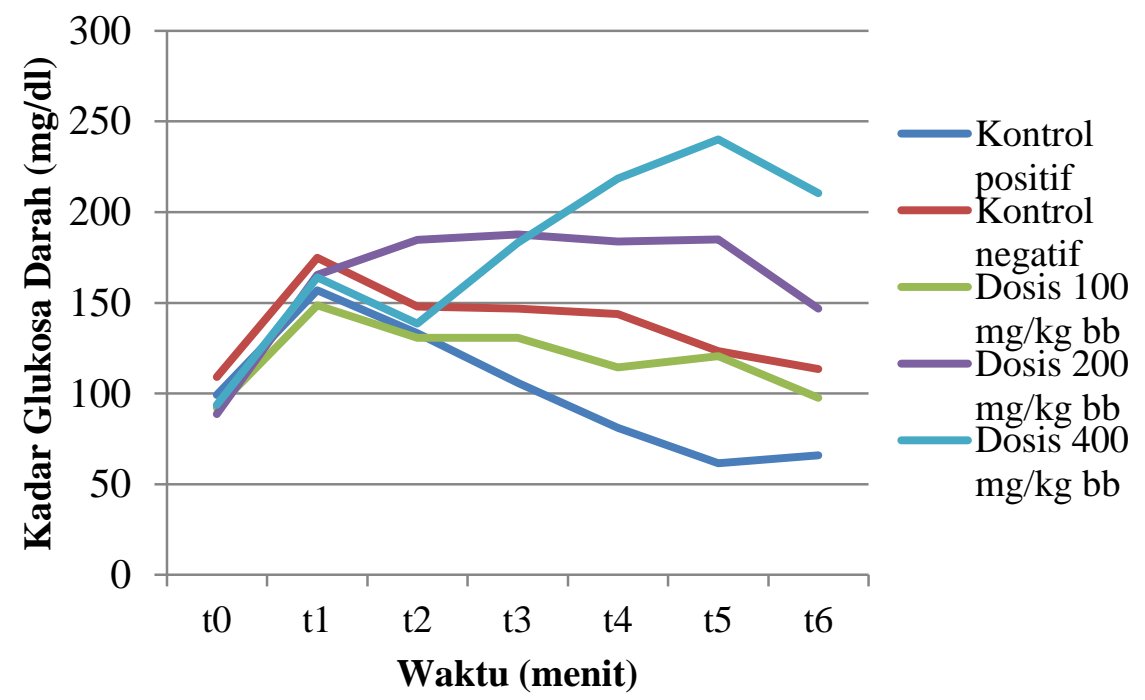

Gambar 1. Grafik kadar glukosa darah mencit

Hasil yang diperoleh dari persentase penurunan kadar glukosa darah mencit, dosis paling efektif dibanding kontrol negatif yaitu pada dosis $200 \mathrm{mg} / \mathrm{kg}$ bb dimana pada kontrol negatif mengalami penurunan kadar glukosa darah mencit sebanyak $8 \%$ pada menit ke-120 (t6) sedangkan pada kelompok uji dengan dosis $200 \mathrm{mg} / \mathrm{kg}$ bb mengalami penurunan kadar glukosa darah mencit sebanyak $21 \%$. Hal ini menunjukkan bahwa ekstrak daun sepat dosis $200 \mathrm{mg} / \mathrm{kg}$ bb merupakan dosis efektif menurunkan kadar glukosa darah mencit.

Dari hasil persentase penurunan kadar glukosa darah mencit, dapat diketahui bahwa ekstrak daun sepat dosis $200 \mathrm{mg} / \mathrm{kg}$ bb lebih berpotensi dibandingkan dengan kontrol positif (glibenklamid) dalam menurunkan kadar glukosa darah mencit pada menit ke 150 (t6). Penurunan kadar glukosa darah mencit yang diberikan ekstrak daun sepat dosis $200 \mathrm{mg} / \mathrm{kg}$ bb pada menit ke 150 (t6) yaitu sebanyak $21 \%$, sedangkan pada kelompok kontrol positif pada waktu ke 150 (t6) mengalami kenaikan kadar glukosa darah mencit sebanyak $7 \%$.

Pada kelompok uji dosis $100 \mathrm{mg} / \mathrm{kg}$ bb, $200 \mathrm{mg} / \mathrm{kg}$ bb, $400 \mathrm{mg} / \mathrm{kg}$ bb terjadi penurunan kadar glukosa darah. Hal ini menunjukkan bahwa ekstrak metanol daun sepat (Mitragyna speciosa) memiliki aktivitas dalam menurunkan kadar glukosa darah mencit (Mus musculus). Efek ini disebabkan karena daun sepat mengandung senyawa metabolit sekunder alkaloid. Menurut Soriton (2014), senyawa alkaloid bekerja dengan cara menstimulasi pelepasan hormon insulin pada pankreas atau menghambat enzim $\alpha$-glukosidase pemecahan karbohidrat yang dapat diserap oleh usus. (t6). 


\section{PENUTUP}

\section{Kesimpulan}

Berdasarkan hasil penelitian yang telah dilakukan maka dapat disimpulkan bahwa ekstrak daun sepat (Mitragyna speciosa) memiliki aktivitas dalam menurunkan kadar glukosa darah. Dosis efektif ekstrak daun sepat dalam menurunkan kadar glukosa darah mencit yaitu dosis $200 \mathrm{mg} / \mathrm{kg}$ bb.

\section{Saran}

Perlu dilakukan pengujian lebih lanjut untuk menguji aktivitas ekstrak daun sepat dengan metode yang berbeda serta dilakukan pengujian lebih lanjut untuk mengisolasi senyawa yang memiliki aktivitas dalam menurunkan kadar glukosa darah dalam ekstrak daun sepat.

\section{DAFTAR PUSTAKA}

Siregar, P.H. 2005., Isolasi Flavonoida dari Daun Tumbuhan Kemuning (Murraya paniculata [L] Jack), Jurnal Sains Kimia (Suplemen). 9. (3). 12-14.

Purintrapiban, J., 2011. Study on Glucose Transport in Muscle Cells by Extracts From Mytragyna speciosa Korth and Mytragynine. Natural Product Research. 25. (15).

Kurniawan, Ari. 2011. Pengaruh Pemberian Ekstrak Jambu Biji (Psidium guajava L) Terhadap Penurunan Kadar Glukosa Darah Tikus Wistar yang Diberikan Beban Glukosa. Artikel Ilmiah. Semarang.

Soriton, H., Paulina V.Y Yamlean., dan Widjaya A. L., 2014. Uji Efektifitas Ekstrak Etanol Daun Tapak Dara (Catharantus roseus) Terhadap Penurunan Kadar Gula Darah Tikus Putih Jantan Galur Wistar (Rattus norvegicus L.) yang Diinduksi Sukrosa. Jurnal Ilmiah Farmasi. 3. (3). 